\title{
Knowledge Mapping Analysis of Finance Research
}

\author{
Caimei Lu1, Danhua Su² \\ ${ }^{1}$ Institute of Management and Decision, Shanxi University, Taiyuan, China \\ ${ }^{2}$ School of Economics and Management, Shanxi University, Taiyuan, China \\ Email: lucaimei@sxu.edu.cn,404289641@qq.com
}

Received 24 October 2015; accepted 15 November 2015; published 18 November 2015

Copyright (C) 2015 by authors and Scientific Research Publishing Inc.

This work is licensed under the Creative Commons Attribution International License (CC BY).

http://creativecommons.org/licenses/by/4.0/

(c) (i) Open Access

\begin{abstract}
Based on 4158 articles from 9 financial journals during 2009-2013 from Web of Science, we use CiteSpace III to construct the knowledge mapping of finance studies. As a result, the primary research power distribution is shown. Further, finance research hotspots and major research fields are revealed via keywords co-occurrence analysis and references co-citation analysis. The findings show that the United States plays a leading role in the research of finance. There are four major research fields: asset pricing, corporate finance, financial intermediation and investor behavior. The findings will contribute to following the international research frontier and catching research trends.
\end{abstract}

\section{Keywords}

Finance, Knowledge Mapping, Major Research Fields, Visualization

\section{Introduction}

Modern finance studies began in the 1950s. After experiencing rapid development in the seventies and eighties, finance has become a significant learning of economic disciplines. Compared with developed countries, China's finance studies are still lagging far behind. Thus, it is significant to learn international finance research focus and development trend, which contributes to tracing international frontier and raising the level of China's financial research.

Knowledge Domain Visualization is a computer-supported information processing technology that can reveal the development process and structure of scientific knowledge in graphical form by analyzing science literature data. In recent years, some scholars apply Knowledge Domain Visualization to learn research hotspots and development dynamics in information science, library science, tourism, statistics and other disciplines [1]-[5]. Up 
to now, there is no literature on international finance research knowledge mapping analysis.

We use CiteSpace III to build financial knowledge maps and have analysed finance research hotspots and main fields in 2009-2013. We are trying to show the overall structure scientifically objectively and visually, so that Chinese scholars can catch the developing trend of finance research effectively.

\section{Data}

Based on 89 journals of business and finance listed in the 2012 annal JCR report (Journal Citation Report) from Web of Science (SCI/SSCI) database, we delete non-financial journals and rank financial journals by 5-year Impact Factor, then select the top 20\%, which includes 9 financial journals (in Table 1). After retrieving the 9 journals from Web of Science with the document format as "Article" and removing the format " news", "meeting abstract", "letter" and other non-original papers, we name the files as "download*.txt". At last we download and save them in their full record formats with references. As a result, there are 4158 articles from 2009 to 2013 , including the authors, title, keywords, abstract and references.

\section{Methods}

We use the method of scientific knowledge map in this paper. Scientific knowledge map is used to show developing process and structure relationships of science knowledge via a visible form. This method involves citation analysis, word frequency analysis, and co-citation analysis. We choose word frequency analysis and co-citation analysis in this paper. By the method of word frequency analysis, we calculate the frequency of keywords in a literature to search research hotspots and reveal their developmental process. Co-citation analysis is the most influential method and can be used not only to reveal the developmental status and changes in the structure of a scientific field, but also to study the research fronts and domains. Co-citation analysis mainly includes document co-citation analysis and author co-citation analysis, through which we can calculate the frequency of cited literatures and cited authors.

We choose CiteSpace III as the research tool. CiteSpace III developed by Chaomei Chen from Drexel University is a knowledge mapping visual software. Based on Java language, this software analyses citation and keywords from scientific literatures, and displays these data in mapping forms. Knowledge maps can not only be able to predict future trends in research but also aid in understanding the current forefronts [6].

\section{Results and Discussion}

\subsection{Research Power Distributions of Finance Research}

The research power distribution of finance research can be deduced from visualization analysis on countries and institutions. On the interface of CiteSpace III, we decide time zone as 2009-2013, set time span as 1, identify network nodes as Country and Institution respectively, choose threshold as top 100, and then run the software to draw finance knowledge maps of countries and institutions. Table 2 and Table 3 show the most productive

Table 1. The 9 representative journals in finance research.

\begin{tabular}{cccc}
\hline Order & Journal Name & 5-Year Impact Factor & Amount of Papers in 5 Years \\
\hline 1 & Journal of Finance & 6.185 & 339 \\
2 & Review of Financial Studies & 5.367 & 5.087 \\
3 & Journal of Financial Economics & 2.46 & 606 \\
4 & Journal of Financial Intermediation & 2.13 & 269 \\
5 & Journal of Financial and Quantitative Analysis & 1.774 & 328 \\
6 & Journal of Corporate Finance & 1.721 & 1367 \\
8 & Journal of Banking \& Finance & 1.7 & 1.597 \\
\hline
\end{tabular}


Table 2. The top-10 most productive countries.

\begin{tabular}{cccccc}
\hline Order & Country & Amount of Papers & Order & Country & Amount of Papers \\
\hline 1 & USA & 2399 & 6 & Netherlands & 170 \\
2 & England & 374 & 7 & France & 152 \\
3 & Germany & 278 & 8 & Switzerland & 135 \\
4 & China & 239 & 9 & Australia & 133 \\
5 & Canada & 238 & 10 & Italy & 131 \\
\hline
\end{tabular}

Table 3. The top-20 most productive institutions.

\begin{tabular}{|c|c|c|c|c|c|}
\hline Order & Institutions & Amount of Papers & Oder & Institution & Amount of Papers \\
\hline 1 & NBER & 148 & 11 & Northwestern Univ & 49 \\
\hline 2 & NYU & 108 & 12 & Duke Univ & 48 \\
\hline 3 & Harvard Univ & 93 & 13 & Indiana Univ & 48 \\
\hline 4 & Univ Penn & 88 & 14 & Ohio State Univ & 47 \\
\hline 5 & Univ Chicago & 85 & 15 & Univ Texas Austin & 45 \\
\hline 6 & Tilburg Univ & 62 & 16 & Cornell Univ & 44 \\
\hline 7 & Boston Coll & 56 & 17 & London Business Sch & 43 \\
\hline 8 & Univ Michigan & 52 & 18 & Univ Calif Berkeley & 42 \\
\hline 9 & Columbia Univ & 51 & 19 & Int Monetary Fund & 42 \\
\hline 10 & Univ N Carolina & 50 & 20 & Fed Reserve Bank New York & 41 \\
\hline
\end{tabular}

top-10 countries and top-20 institutions respectively. Figure 1 and Figure 2 both directly display amount and time of literatures from countries or institutions in the form of "annual ring", The thickness of the ring is in proportion to the amount of issued papers in a given time slice. A larger ring indicates a higher frequency.

It can be seen from Figure 1 that there are 2399 papers from America in 2009-2013, which accounts for 57.7\% of the total publication amount. It shows America plays a leading role in finance research field. England, Germany and China rank second, third and fourth place respectively.

Figure 2 shows finance literatures are mainly from The National Bureau of Economic Research (NBER), New York University (NYU), Harvard University (Harvard Univ), University of Pennsylvania (Univ Penn) and University of Chicago (Univ Chicago). The amount of issued literatures from NBER ranks first, New York University ranks second and Harvard University ranks third. There are 17 of the top-20 institutions are from America and account for $85 \%$. The top-ranking institutions of China include National Taiwan University (Natl Taiwan Univ), Hong Kong University Science \& Technology (Hong Kong Unic Sci \& Technol) and University of Hong Kong (Univ Hong Kong). They rank 25th, 28th and 38th respectively. However, China's mainland institutions fail to enter the top 100. We can deduce from Figure 2 that most institution nodes have obvious connection with other institution nodes, which means that institutions cooperate frequently in finance research.

\subsection{Representatives in Finance Research Field}

We can identify representatives of one discipline by author co-citation analysis. Running CiteSpace III software, we choose node type as Cited Author, select threshold for Top 100, and then draw an author co-cited knowledge map (Figure 3). Table 4 shows the top-20 most-cited authors. Each node in Figure 3 represents an author. A larger node means the author is cited frequently in co-citation network. The key nodes in network have high centrality. Each line between nodes represents a co-citation relationship of authors.

It can be seen from Figure 3 and Table 4 that the citation frequency of the American scholar Fama from America is the most. The efficient market hypothesis (EMH) [7] pointed by Fama in early time becomes a cornerstone of modern finance theories. In addition, Fama has written many influential academic papers on investment portfolio, asset pricing, corporate finance and monetary theory. Because of the outstanding contribution 


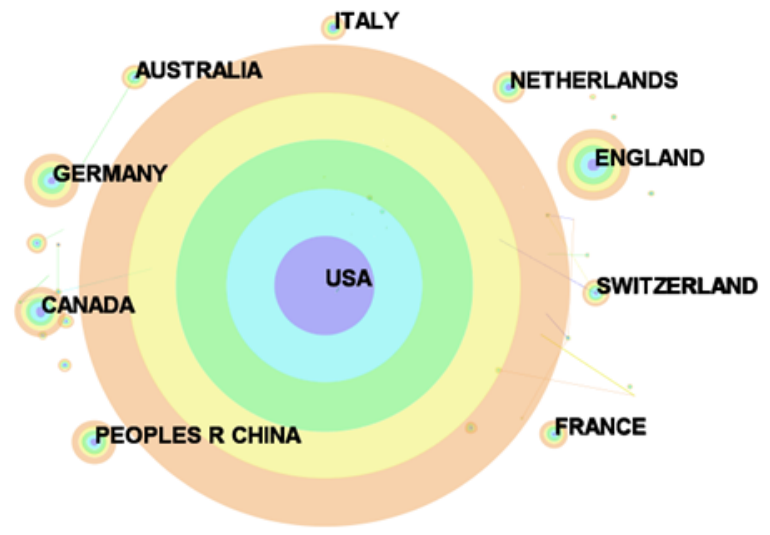

Figure 1. Country distribution map of finance research.

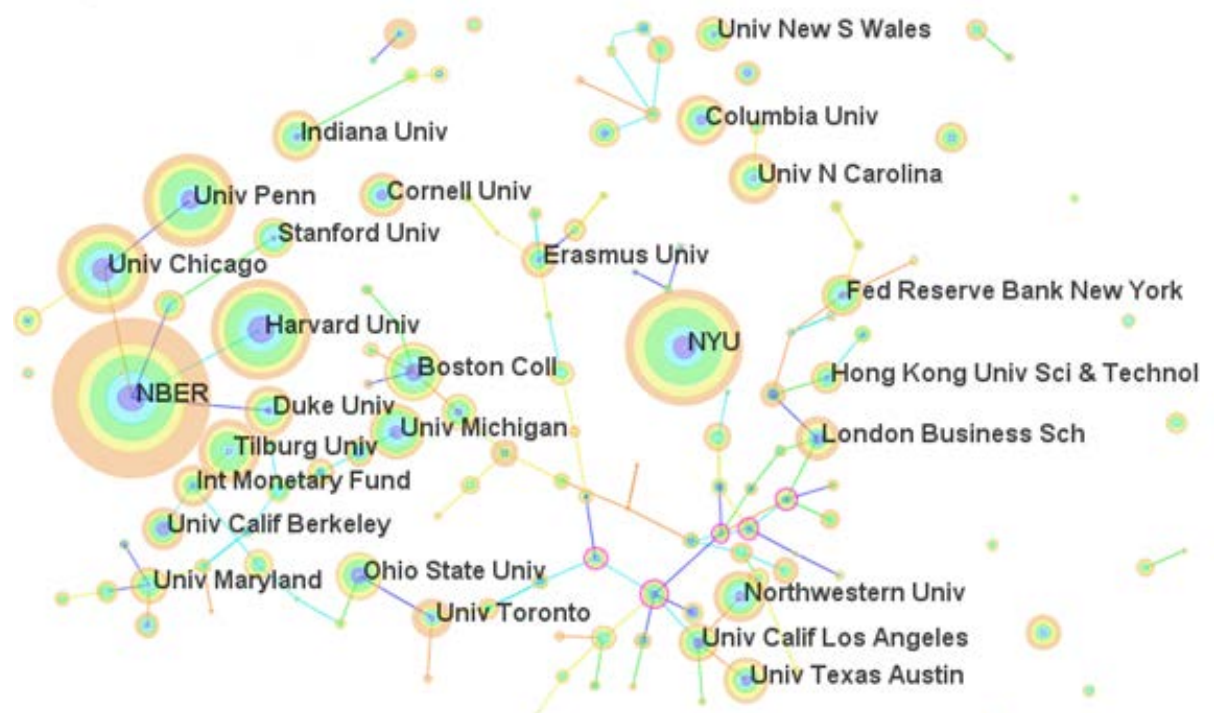

Figure 2. Institution distribution map of finance research.

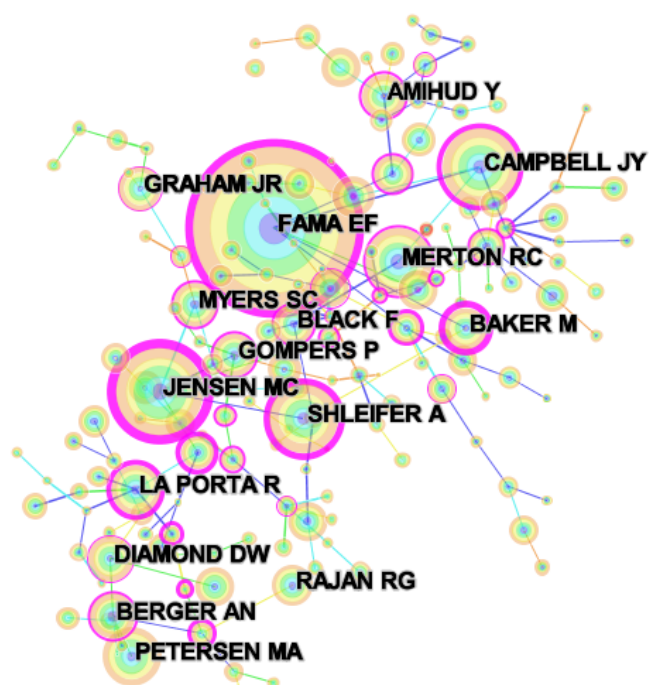

Figure 3. Author co-citation knowledge map of finance field. 
Table 4. The top-20 most cited authors.

\begin{tabular}{cccccccc}
\hline Order & Author & Cited Frequency & Centrality & Order & Author & Cited Frequency & Centrality \\
\hline 1 & Fama EF & 1231 & 1.17 & 11 & Myers SC & 336 & 0.29 \\
2 & Jensen MC & 657 & 1.3 & 12 & Graham JR & 329 & 0.12 \\
3 & Campbell JY & 590 & 0.65 & 13 & Baker M & 328 & 0.93 \\
4 & Shleifer A & 527 & 0.93 & 14 & Rajan RG & 326 & 0.02 \\
5 & Merton RC & 510 & 0.34 & 15 & Black F & 323 & 0.31 \\
6 & Petersen MA & 461 & 0.01 & 16 & Gompers P & 323 & 0.39 \\
7 & La Porta R & 395 & 0.61 & 17 & Ang A & 322 & 0.09 \\
8 & Amihud Y & 354 & 0.29 & 18 & Acharya VV & 317 & 0.05 \\
9 & Diamond DW & 353 & 0.18 & 19 & Newey WK & 312 & 0.02 \\
10 & Berger AN & 351 & 0.31 & 20 & Allen F & 308 & 0.01 \\
\hline
\end{tabular}

was awarded Nobel prize in Economics Science in October, 2013.

The cited author ranking No. 2 is Jensen from America. Jensen's most important contribution in finance is the agency cost theory [8]. It brings agency problem into corporation finance analysis. The agency cost theory integrates the theory of property rights, the theory of agency and the theory of finance into research, and developed corporation capital structure and organization structure in detail on the condition of asymmetric information. It has been widely used in finance. In addition, Jensen built the Journal of Financial Economics which has been one of the three most influential financial journals.

The cited author ranking No. 3 is Professor Campbell from Harvard University. Campbell has published more than 60 academic papers in top journals which include American Economic Review, Journal of Finance and Journal of Political Economy. He had served as a director of an asset pricing program in the National Bureau of Economic Research, and then he was elected to be the president of the United States Financial Association in 2005. Campbell's contribution is the further study on long-term portfolio selection and financial market econometrics. His empirical research in long-term asset allocation has won the prestigious Paul A Samuelson Prize for three times (in 1997, 1999 and 2002).

The cited authors ranking in the top also include Shleifer, Merton and Black. The corresponding nodes in Figure 3 also indicate a high centrality. It means these scholars connect different research fields, and they have played a crucial role of "bridge" in the whole network of finance research.

\subsection{Hotspots in Finance Research}

A paper's keywords can highly generalize and concentrate on its theme. Analysis on high frequency keywords is a main researching content in relevant fields. We search high-frequency keywords via word frequency analysis to reveal the hotspots in research fields. We use keywords co-cition knowledge map drew by CiteSpace III to explore hotspots in finance. On the CiteSpace III interface, we choose node type as Keywords, and set the threshold as Top 100. Then a keyword co-citation knowledge map in finance (Figure 4) and the top-20 high-frequency words (Table 5) are obtained. The sizes of nodes represent the corresponding frequencies of keywords. A bold line connecting two nodes indicates a high co-occurred frequency of the two corresponding keywords.

It can be seen obviously from Figure 4 and Table 5, the hotspots in finance research consist of two clusters. The first cluster is about asset pricing and empirical analysis, which includes market, information, stock returns, liquidity, model, cross-section, prices, volatility and equilibrium. The second cluster is about corporate finance theory and empirical analysis, which includes such as keywords risk, performance, returns, investment, corporate governance, firm, ownership, capital structure and debt.

\subsection{Finance Research Fields and Representative Literatures}

A document co-citation knowledge map can show a discipline's main research fields or direction [9]. We can use timeline which is clustered by co-cited literatures to classify cited literature by category in time sequence. 


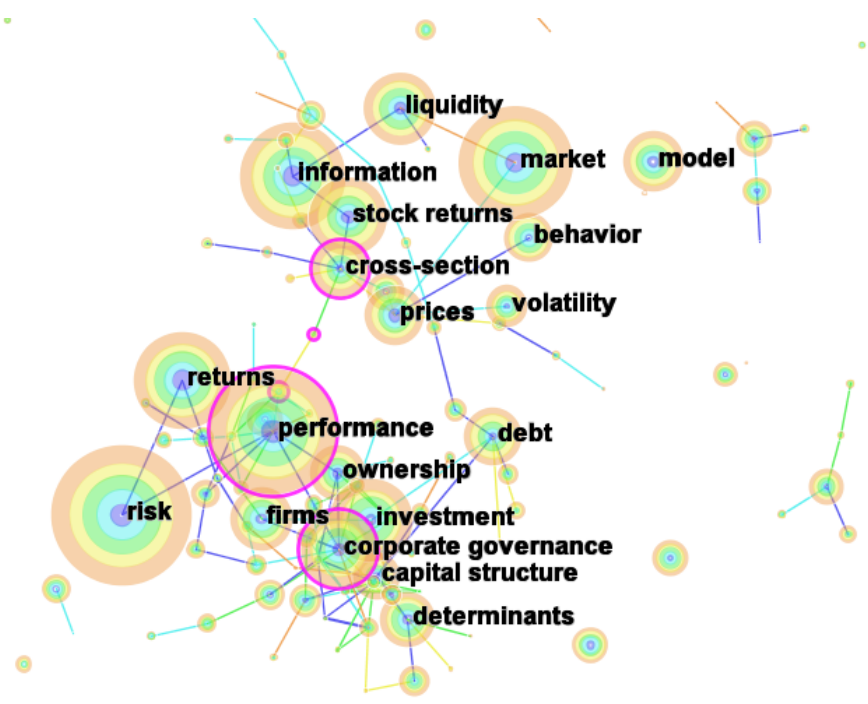

Figure 4. Keywords co-citation knowledge map in finance.

Table 5. The top-20 high-frequency keywords of finance research.

\begin{tabular}{cccccc}
\hline Order & Keyword & Frequency & Order & Keyword & Frequency \\
\hline 1 & risk & 641 & 11 & model & 284 \\
2 & performance & 566 & 12 & debt & 276 \\
3 & market & 526 & 13 & prices & 274 \\
4 & information & 483 & 14 & ownership & 268 \\
5 & returns & 455 & 15 & cross-section & 263 \\
6 & investment & 385 & 16 & determinants & 259 \\
7 & stock returns & 365 & 17 & behavior & 237 \\
8 & corporate governance & 361 & 18 & capital structure & 229 \\
9 & liquidity & 332 & 19 & volatility & 205 \\
\hline
\end{tabular}

It's useful in tracking the developmental process of co-cited literatures. The cited frequency and centrality indicate the literature's influence in its research field. The most-cited frequency means scholars are paying more attention to the corresponding literature which sits in a significant situation [10]. Therefore, we use cited frequency and centrality to select finance representative literatures in this paper.

We choose node type as Cited reference, and set the threshold as top 200 and cluster automatically, then use LLR (Log-likelihood-ratio) method to select titles of citing literatures as the cluster labels. Then we obtain the document co-citation knowledge map of finance (Figure 5), the timeline visualization of document co-citation cluster (Figure 6) and document co-citation clusters (Table 6). Figure 5 shows four main fields and 21 branches, which are classified by the aggregation degree in the near 5 years. Figure 6 shows the arrangement of cited literatures in time sequence in each branch.

In addition, according to co-cited literatures lists and citing literatures lists from the 21 branches obtained by CiteSpace III, we select the representative literatures in main research fields of finance from Table 7. Representative literatures in 2009 and before are selected from the co-cited literatures, which show their most-cited frequency. Representative literatures after 2009 are selected from the citing literatures, which show their high centrality.

\subsubsection{Main Field 1: Asset Pricing (Field A in Figure 5)}

Asset pricing (Field A in Figure 5) is one of the main fields in finance research, which is studied in detail and is contributed the most. It can be seen from Figure 5 that asset pricing field includes \#1, \#2, \#9, \#14, \#15, \#17 and 


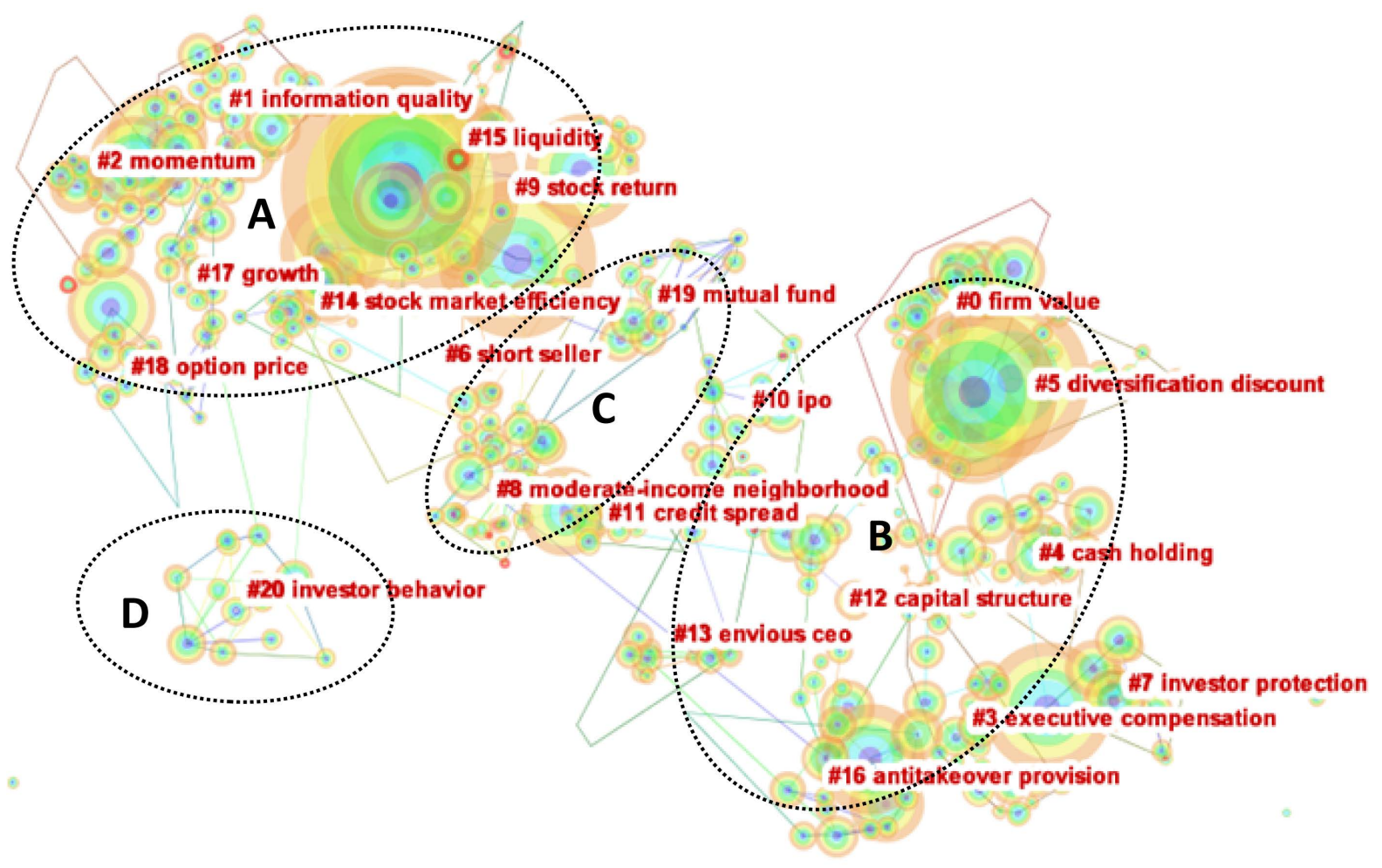

Figure 5. The document co-citation knowledge map of finance research.

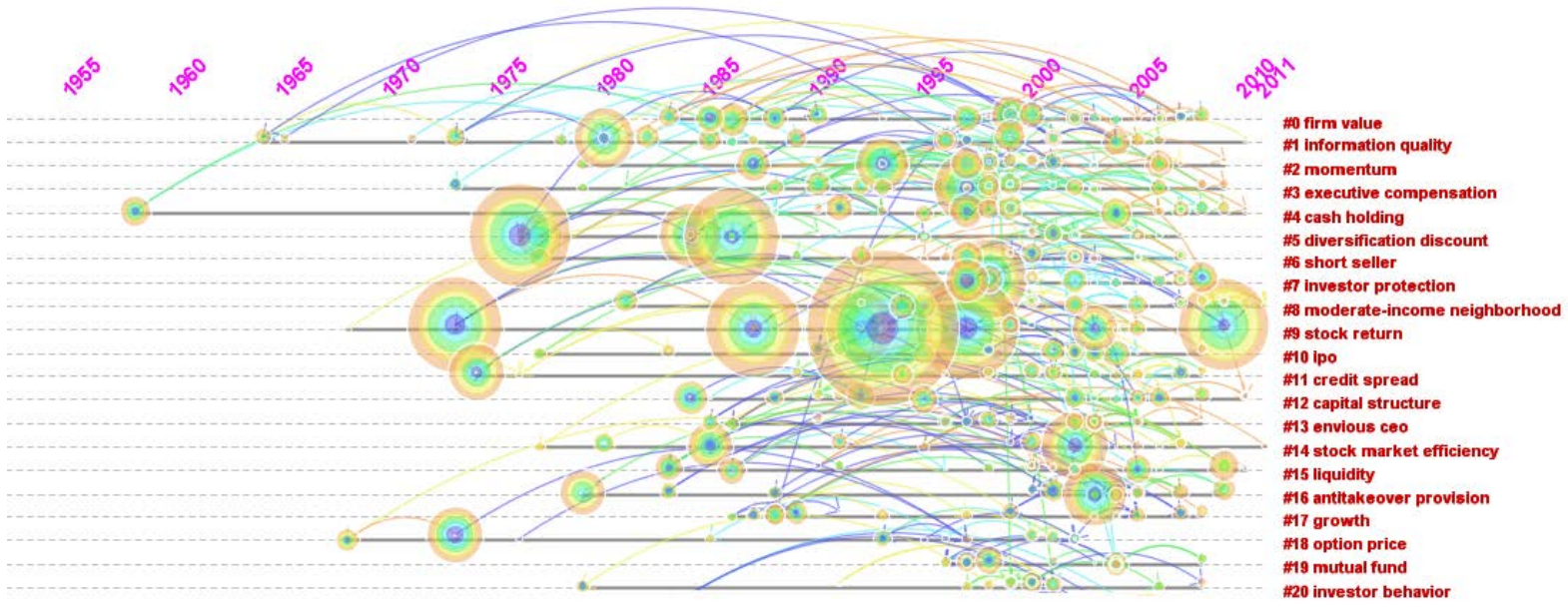

Figure 6. The timeline visualization of document co-citation clusters.

\#18. It is studied from the perspectives of theories and empirical analysis to determine values of assets and derivative tools. This field provides price foundation for trades of assets and derivative tools in capital market.

Asset pricing theories and empirical analysis are studied in \#1, \#9, \#14 and \#17 on risks, returns and market efficiency respectively. The most-cited literature in this aspect is Common risk factors in the returns on stocks and bonds published by Fama and French (1993) [11] from America in Journal of Financial Economics. It has put forward the famous Fama-French three-factor model. In this model, the excess return of an investment portfolio (includes single stocks) can be explained by three factors: market assets portfolio (Rm-Rf), market value (SMB) and book to market (HML). It modified the capital asset pricing model (CAPM), which indicates that the excess return is not only related with system risks, but also with corporate sizes and values. Carhart (1997) has built a four factors model based on the Fama-French three-factor model, which added the factor momentum 
Table 6. Document co-citation clusters.

\begin{tabular}{|c|c|c|c|}
\hline Cluster & Size & Silhouette & Top Terms by LLR $(\mathrm{P}=0.0001)$ \\
\hline$\# 0$ & 25 & 0.94 & (55.43) firm value; (46.44) international study; (44.04) sovereign wealth fund investment \\
\hline$\# 1$ & 25 & 0.949 & (67.06) information quality; (59.73) long-run risk; (30.19) subjective expectation \\
\hline$\# 2$ & 24 & 0.982 & (53.85) momentum; (44.49) idiosyncratic risk; (41.83) return \\
\hline$\# 3$ & 23 & 0.966 & (69.7) executive compensation; (68.4) long-term perspective; (68.4) new view \\
\hline$\# 4$ & 22 & 0.991 & (105.04) cash holding; (71.58) financial constraint; (49.81) real effect \\
\hline$\# 5$ & 21 & 0.945 & (59.17) diversification discount; (28.62) property-liability insurer; (28.62) portfolio risk \\
\hline$\# 6$ & 21 & 0.963 & (59.07) short seller; (30.04) short selling; (27.91) costly arbitrage \\
\hline$\# 7$ & 20 & 0.988 & (54.39) investor protection; (43.55) corporate ownership; (39.75) political right \\
\hline$\# 8$ & 19 & 0.986 & $\begin{array}{l}\text { (41.33) moderate-income neighborhood; (41.33) bank branch presence; } \\
\text { (39.74) lending relationship }\end{array}$ \\
\hline$\# 9$ & 18 & 0.951 & (52.56) stock return; (43.28) cross-section; (29.65) performance \\
\hline$\# 10$ & 18 & 0.925 & (118.2) IPO; (46.32) town; (43.35) new game \\
\hline$\# 11$ & 18 & 0.911 & (93.55) credit spread; (56.56) capital structure; (45.59) permanent shock \\
\hline$\# 12$ & 18 & 0.933 & (37.97) capital structure; (28.2) debt structure; (26.42) capital structure adjustment speed \\
\hline$\# 13$ & 17 & 0.906 & (36.11) envious CEO; (36.11) merger wave; (25.69) market discount \\
\hline$\# 14$ & 17 & 0.909 & (26.38) stock market efficiency; (26.38) dealer market; (26.38) trading volume \\
\hline$\# 15$ & 17 & 0.946 & (52.37) liquidity; (22.15) bank; (21.94) probability \\
\hline$\# 16$ & 16 & 0.969 & (26.88) antitakeover provision; (26.12) auction; (26.12) threat \\
\hline$\# 17$ & 16 & 0.97 & (65.1) growth; (43.22) rent; (41.02) out-of-sample equity premium prediction \\
\hline$\# 18$ & 15 & 0.946 & (65.55) option price; (45.99) levy jump diffusion process; (45.99) detecting jump \\
\hline$\# 19$ & 14 & 0.957 & (127.32) mutual fund; (112.41) hedge fund; (73.88) performance \\
\hline$\# 20$ & 14 & 0.937 & (73.4) investor behavior; (61.64) individual investor; (43.97) nature \\
\hline
\end{tabular}

characteristics of security returns into the model. The model can reduce average pricing errors obviously, and reflect the variation of average security return of cross section in detail. Campbell (2001) applied VaR (Value-atRisk) model into portfolio selection and capital asset pricing. Later he (2010) analysed decisive factors of growth stocks' systematic risks on stock returns. Kelly and Ljungqvist (2012) have studied the significant role of asymmetric information in asset pricing.

The method of econometrics is often used in empirical research of asset pricing. There are many cited literatures published in Econometrica. For example, White (1980) put forward the heteroskedasticity-consistent covariance matrix estimator when the form of heteroskedasticity is unknown, and solved the problem of heteroskedasticity efficiently by a direct test (cited 185 times). However, this method doesn't work when the residual sequence has autocorrelation. In 1987, Newey and West improved the heteroskedasticity-consistent covariance matrix estimator and proposed the HAC (heteroskedasticity-autocorrelation-consistent) estimator (cited 291 times). It still works when heteroskedasticity and autocorrelation are coexisted. For many panel data, residuals often relate to time sequence or corporations and lead to biased errors from stardard errors in the method of ordinary least square (OLS). Peterson from America has published Estimating standard errors in finance panel data sets: comparing approaches in Review of Finance Studies in 2009. In this paper, he compared effects of different kinds of biased errors via different algorithms and proposed some directive advices to each kind of biased errors (cited 275 times).

Cluster \#2 is connected in monmentum effect. Jegadeesh and Titman (1993) [12] proposed the theory of monmentum effect, which indicates a similar pattern of returns around the earning announcements of past winners and losers is also documented. Jegadeesh and Titman studied the returns in New York Stock Exchange (NYSE) and American Stock Exchange (AMEX) in 1965-1989. They found that better-return stocks in the past $3-12$ 
Table 7. Main research fields of finance and representatives.

\begin{tabular}{|c|c|c|c|c|}
\hline Order & Field & Literature Title and Publish Date & Author & $\begin{array}{l}\text { Citation } \\
\text { Frequency/ } \\
\text { Centrality }\end{array}$ \\
\hline \multirow{8}{*}{1} & \multirow{8}{*}{$\begin{array}{l}\text { Asset } \\
\text { pricing }\end{array}$} & $\begin{array}{l}\text { Common risk factors in the returns on stocks and bonds } \\
\text { (1993) }\end{array}$ & Fama and French & 434 \\
\hline & & On persistence in mutual fund performance (1997) & Carhart & 290 \\
\hline & & $\begin{array}{l}\text { Estimating standard errors in finance panel data sets: } \\
\text { Comparing approaches (2009) }\end{array}$ & Petersen & 275 \\
\hline & & $\begin{array}{l}\text { Illiquidity and stock returns: Cross-section and } \\
\text { time-series effects (2002) }\end{array}$ & Amihud & 194 \\
\hline & & The pricing of options and corporate liabilities (1973) & Black and Scholes & 163 \\
\hline & & $\begin{array}{l}\text { Returns to buying winners and selling losers: } \\
\text { Implications for stock market efficiency (1993) }\end{array}$ & Jegadeesh and Titman & 163 \\
\hline & & $\begin{array}{l}\text { Growth or glamour? Fundamentals and systematic risk } \\
\text { in stock returns (2010) }\end{array}$ & Campbell et al. & 0.66 \\
\hline & & $\begin{array}{l}\text { A simple way to estimate bid-ask spreads from daily } \\
\text { high and low prices (2012) }\end{array}$ & Corwin and Schultz & 0.58 \\
\hline \multirow{8}{*}{2} & \multirow{8}{*}{$\begin{array}{l}\text { Corporation } \\
\text { finance }\end{array}$} & $\begin{array}{l}\text { Theory of the firm: managerial behavior, agency costs } \\
\text { and ownership structure (1976) }\end{array}$ & Jensen and Meckling & 305 \\
\hline & & Law and finance (1998) & Lopez-de-Silanes et al. & 236 \\
\hline & & Corporate governance and equity prices (2003) & Gompers et al. & 202 \\
\hline & & $\begin{array}{l}\text { Corporate financing and investment decisions when } \\
\text { firms have information that investors do not have (1984) }\end{array}$ & Myers and Majluf & 191 \\
\hline & & A survey of corporate governance (1997) & Shleifer and Vishny, & 103 \\
\hline & & What matters in corporate governance? (2009) & Bebchuk et al. & 98 \\
\hline & & $\begin{array}{l}\text { Local underwriter oligopolies and IPO } \\
\text { underpricing (2011) }\end{array}$ & Liu and Ritter & 0.65 \\
\hline & & $\begin{array}{l}\text { Corporate governance and value creation: Evidence from } \\
\text { private equity (2013) }\end{array}$ & Acharya et al. & 0.43 \\
\hline \multirow{5}{*}{3} & \multirow{5}{*}{$\begin{array}{c}\text { Finance } \\
\text { intermediation }\end{array}$} & $\begin{array}{l}\text { Financial intermediation and delegated monitoring } \\
\text { (1984) }\end{array}$ & Diamond & 104 \\
\hline & & $\begin{array}{l}\text { Measuring mutual fund performance with } \\
\text { characteristic-based benchmarks (1997) }\end{array}$ & Daniel et al. & 78 \\
\hline & & $\begin{array}{l}\text { Does function follow organizational form? Evidence } \\
\text { from the lending practices of large and small banks } \\
(2005)\end{array}$ & Berger et al. & 73 \\
\hline & & $\begin{array}{l}\text { This time is the same: using bank performance in } 1998 \\
\text { to explain bank performance during the recent financial } \\
\text { crisis (2012) }\end{array}$ & Fahlenbrach et al. & 0.5 \\
\hline & & A model of shadow banking (2013) & Gennaioli et al. & 0.35 \\
\hline \multirow{5}{*}{4} & \multirow{5}{*}{$\begin{array}{l}\text { Investor's } \\
\text { behave-ours }\end{array}$} & $\begin{array}{l}\text { Prospect theory: an analysis of decisions under risk } \\
\text { (1979) }\end{array}$ & Kahneman and Tversky & 57 \\
\hline & & A model of investor sentiment (1998) & Barberis et al. & 52 \\
\hline & & $\begin{array}{l}\text { All that glitters: the effect of attention and news on the } \\
\text { buying behavior of individual and institutional } \\
\text { investors (2008). }\end{array}$ & Barber and Odean & 47 \\
\hline & & $\begin{array}{l}\text { Nature or nurture: what determines investor } \\
\text { behavior? (2010) }\end{array}$ & Barnea et al. & 0.45 \\
\hline & & Global, local, and contagious investor sentiment (2012) & Baker et al. & 0.42 \\
\hline
\end{tabular}

Notes: Co-cited frequency means the co-cited times of a literature which is selected from 9 journals during 2009-2013. In the last column, it shows the co-cited frequency of literatures published before 2009 and the centrality of literatures published after 2009. 
months will still get better returns in the next $3-12$ months, while the worse return stocks will still get worse returns in the same time interval. Rouwenhorst (1998) employed this method into stock markets from 12 European countries and found the results are consistent with the momentum effect in American market. The momentum effect generally exists in stock market all over the world, which attracts more and more scholars to explore the reasons. Fama and French (1996) found that Fama-French three-factor model can explain the small firm effect and long-term reversal effect, but it can't explain the short-term momentum effect. Jegadeesh and Titman (2001) found the data of stock returns also show this profitable momentum effect since the 1990s. However, the current methods of risk measure can't comprehensively explain the momentum returns. In the research of multiple assets, scholars usually study momentum factor together with value factor, such as Fama and French (2012), and Asness, Moskowitz and Pedersen (2013). Some scholars study momentum factor together with reversal/ mean reversion, such as Balvers and $\mathrm{Wu}(2006)$, and Vayanos and Woolley (2013).

Cluster \#15 is involved in asset pricing from the perspective of liquidity. In traditional hypothesis of asset pricing, assets can always be sold. However, when liquidity is restricted, compared with liquid market, many issues need to be resolved such as asset equilibrium prices, portfolios and the measure of illiquid risks in illiquid market. On this aspect, Amihud and Mendelson (1986) [13] proposed the theory of liquidity premium creatively. Based on the micro costs of transaction, they used bid-ask spread to measure liquidity, and then inferred the relationship between expected returns and bid-ask spread. Furthermore, Amihud (2002) built an illiquidity index "ILLIQ" via prices and trading volume to measure liquidity and made empirical analysis by the statistics from NYSE during 1963-1997. Pastor and Stambaugh (2003) have studied the relationship between liquidity risks and expected stock returns. They found liquidity is an important state variable in asset pricing models. Corwin and Schultz (2012) proposed a new method of bid-ask spread to measure liquidity based on the daily highest price and the daily lowest price. They pointed out this method calculates easily and is more effective than other estimates.

Cluster \#18 is concerned in option pricing. This aspect is started from The pricing of options and corporate liabilities published by Black and Scholes (1973) [14]. Based on the non-arbitrage analysis, they deduced the famous Black-Scholes option pricing model from assuming that stock prices follow the random walk and logarithmic normal distribution. It has made a breakthrough in financial derivative asset pricing. Later, Merton (1974) extended Black-Scholes model, and proposed a syntactic model to calculate corporations' debt defaults. Due to their outstanding contribution on option pricing, Scholes and Merton awarded the Nobel Prize in Economics in 1997. The Black-Scholes option pricing model is based on a harsh assumption and is only available for European option pricing, Heston (1993) proposed the Stochastic volatility model (SV). SV model has been widely used in empirical analysis because of its convenience. Pan (2002) studied jump-risk premia from the America S\&P500 stock index option. He found that it is crucial to introduce the jump stock price behaviour in explaining the behavior of option price (in time sequence and cross section). Besides, many scholars have done further research such as Christoffersen (2010), Grundy (2012), and Polkovnichenko and Zhao (2013).

\subsubsection{Main Field 2: Corporation Finance (Field B in Figure 5)}

The main field of finance research also includes corporation finance. In recent years, this field mainly refers to financing and capital structure (\#4, \#5, \#11,\#12,\#13), IPO underpricing (\#10) and corporate governance (\#0, \#3, \#7, \#16).

Financing and capital structure is the core of corporation finance. According to time lines in Figure 6, the first literate on this aspect is The cost of capital, corporation finance and the theory of investment published in American Economic Review by Modigliani and Miller [15] in 1958. They presented the famous MM theory in this literature. The main idea of MM theory is that a corporation's market value is irrelevant with its capital structures in a perfect capital market. Later, this theory was improved by Modigliani and Miller and other scholars. Since the 1970s, asymmetric information theory is introduced into corporate capital structure in further research. Jensen and Meckling (1976) studied corporation capital structure from agency costs of equity financing. They proposed agency cost theory in Theory of the firm: managerial behaviour, agency costs and ownership structure. Myers and Majluf (1984) proposed pecking order theory. Jensen (1986) proposed free cash flow hypothesis. In the late 1990s, a part of scholars start studying corporation capital structure from the perspective of behaviour finance. Stein (1996) put forward the concept of market timing clearly after studied rational capital budgeting in an irrational world in detail. He believes that rational managers will issue more stocks by using the merit of low costs of equity financing if a company's stock price is overvalued in the market. On the contrary, 
when the stock price is underestimated, rational managers will repurchase these stocks to maximize the company value. Baker and Wurgler (2002) formally proposed the market timing theory and made empirical research. They believed capital structure is the accumulated result of financing based on the market timing in the past, and corporations have no optimal capital structure. Huang and Ritter (2009) reviewed the market timing theory from a new angle. They employed equity financing costs to test the mode of financing decision and the effect of capital structure in different ways of financing. They pointed out market timing is an essential factor for corporations in choosing which stock or bond to be issued. Fan (2012) examined how the institutional environment influences capital structure and debt maturity choices of firms in 39 developed and developing countries.

IPO (Initial Public Offering) underpricing is an important aspect in the research of corporate financing behaviours in recent years. The behaviour that a firm issued its common stock to public for the first time in primary market is known as IPO. The phenomenon that a stock's issue price is lower than its trading price is known as IPO underpricing. The IPO prices are often underestimate in many countries. Ibbotson (1975) [16] first studied IPO underpricing in detail based on newly public companies from America during the period 1960 through 1969. The paper provides insight into his underpricing mystery, but does not solve it. Scholars attempt to study IPO underpricing from the angle of information asymmetry, institutional factors, regulations and behaviour finance. Baron (1982) explained IPO underpricing based on information asymmetry between public companies and underwriters. Rock (1986) believed the information asymmetry among investors is the real reason of IPO underpricing. Loughran and Ritter (2002) explained causes of IPO underpricing from the perspective of theory. Moreover, Loughran and Ritter (2004) studied the variation of IPO underpricing during 1980-2003. They believed the IPO underpricing is generated from the changed aims of managers in public companies, which leads to additional agency costs. Liu and Ritter (2011) explained causes of IPO underpricing through the analysis of underwriting market competition. So far, no theory can comprehensively explain the reason of IPO underpricing.

Corporate governance has been concerned in finance research since the 1990s. Shleifer and Vishny (1997) [17] pointed out that the essential issue of corporate governance is how to ensure investors' benefit in their investment activities. Gompers (2003) measured shareholders' rights by constructing a comprehensive G index. They divided 24 corporation governance provisions from IRRC into 5 sections: tactics of delaying hostile take-over, right to vote, protection on directors or managers, other take-over defensive measures and national laws. Then they assigned these provisions based on actual corporate situations, and summed the scores and obtained a $\mathrm{G}$ index. Similarly, Bebchuk (2009) constructed an E index by 6 of the 24 provisions. Erkens (2012) analysed the influence of corporate governance on performance of corporations during the financial crisis during 2007-2008. By organizing the data from 296 financing corporations in 30 countries, he found corporations with independent directors and holding more stocks gained worse returns during the crises. Acharya (2013) found that mature private equity funds can produce values for acquiring corporations by supervising and governing actively.

\subsubsection{Main Field 3: Financial Intermediaries (Field C in Figure 5)}

Financial intermediation is concerned in recent years. In this field, cluster \#6, \#8 and \#19 introduce theories of financial intermediation, the operation of financial intermediate institutions and performance evaluation respectively.

The literature with the most-cited frequency in financial intermediation is Financial intermediation and delegated monitoring published by Diamond (1984) [18] in Review of Financial Studies. Diamond has built the famous delegated monitoring model. Allen and Santomero (1998) explained the existence of financial intermediation by reducing investors' participating costs and providing risk management. Scholtens and Wensveen (2000) criticised and supplied the theory of Allen and Santomero (1998). They believed participating costs cannot comprehensively explain some huge variations in finance in recent years. For instance, the development of mutual funds and the widely use of financial derivative instruments. The key reason of rapid development of these financial products is risks rather than participating costs.

The operation management and performance evaluation of financial intermediate institutions are main aspects of financial intermediation. Daniel, Grinblatt, Titman and Wermers (1997) [19] developed a indicator of evaluating performance of mutual funds, which used benchmark based on the characteristics stocks held by portfolio (DGTW system). Sirri and Tufano (1998) studied capital's inflow and outflow of mutual funds in Costly search and mutual fund flows. Investors make decisions according to the past performances of funds. They would like to apply those performed outstanding in the past. Cost searching is a decisive factor of fund flow. 
Berger (2005) found that small banks are able to collect more soft information than big banks. Big banks are unwilling to loan to firms lacking of financial information, and the credit constraint therefore cannot be relieved effectively. Aggarwal and Jorion (2010) analysed emerging hedge funds and managers in detail. Huang (2011) studied the relationship between performance of mutual funds and risk shifting. Fahlenbrach (2012) studied whether bank performance during financial crisis in 1998 can predict its bank performance in recent financial crisis period. It turned out that because of continuity of banking business models, performance in a new crisis can be predicted by the past performance in past crises. Gennaioli (2013) studied the relationship between shadow banking system and financial stability by a model of activities of shadow banks. The result indicated that shadow banking system is stable and it helps improving the social welfare in rational expectation hypothesis. However, the shadow banking activities may lead to systematic risks and financial fragility if participants underestimate the tail risks.

\subsubsection{Main Field 4: Investors' Behaviours (Field D in Figure 5)}

Cluster \#20 is included in field D from the perspective of investors' behaviours. There are two aspects in this field. The first aspect is decision making process based on investors' psychological deviation. Another aspect is focused on investors' irrational behaviours, reasons and difference in capital market.

In traditional finance, we presume investors in finance market are rational. They often follow the principle of maximizing the interests to make the optimized decision. However, in the realistic economic activities, investors often make deviate decisions which are inconsistent with the traditional optimal behaviours. These deviations reflect the characteristics of investors' irrational behaviours, which is hard to explain via traditional rational hypothesis.

Kahneman and Tversky [20] put forward the prospect theory in Prospect theory: an analysis of decisions under risk in 1979, which laid a theoretical foundation in finance research. In 1982, Kahneman, Tversky and Slovic proposed it will violate Bayes rule or other relevant theories when individuals make decisions in uncertain situation. On the contrary, they will perform systematic cognitive deviations and empirical deviations. Barberis, Shleifer and Vishny (1998) proposed the BSV model. They believed investors will produce representative deviations and conventional deviations when make decisions, which will lead to two kinds of mistakes in decision: under-reaction and over-reaction. Odean (1998) analysed account information from 10,000 discount brokers and 162,948 transaction data during 1987.1-1993.12 from a securities trading department in America. Then they proved that individual investors are able to behave obvious disposition effect and analysed the causes. According to the empirical analysis of account information made by individual investors, Barber and Odean (2008) discovered the effect of attention in buying decision is greater than selling decision. Barberis and Xiong (2009) have discussed causes of disposition effect based on the value function of prospect theory. Barnea (2010) analysed the influence of genetic factors on investors' behaviours via statistics of twin investment portfolio. Baker and Wurgler (2012) analysed stock markets from 6 countries (contains Canada, France, Germany, Japan, England and America) during 1980-2005. They have built the global index of investors' sentiment and local index of investors' sentiment, and discovered these two investor sentiments are essential reversing forecast for market proceeds in statistics and economics. They pointed out that investors' sentiments are contagious because of the international capital flows. Besides, Hoffmann (2013) studied individual investors' views and behaviours during the finance crisis during 2008-2009.

\section{Conclusion}

We select 9 financial journals from Web of Science during 2009-2013 as the sample in this paper. By using CiteSpace software, we analyse finance literatures from countries, research institutions, representatives, hotspots and fields respectively. Then we draw the following conclusions. First, from the power distribution in finance research, we discover that America plays a leading role. The amount of issued literatures from America is the most, which accounts for $57.7 \%$ of the total. $85 \%$ of the top- 20 core institutions and $95 \%$ of the top- 20 core authors are from America. The main representatives in finance research include Fama, Jensen, Campbell, etc. The amount of issued papers from China ranks the fourth, the most of which are written by scholars from Hong Kong and Taiwan. However, universities and research institutes from mainland fail to rank the top-100. Second, finance hotspots are focused on the fields of asset pricing and corporation finance, which mainly include risk, performance, market, information, return, investment, corporation governance, liquidity, ownership, behaviours, 
capital structure and volatility. The last, the main fields of finance research involve asset pricing, corporation finance, finance intermediaries and investors' behaviours. We sum up representative literatures and progress of finance research. In further research, there are many issues worthy of researching deeply, such as the further study of changes and trends of finance research.

\section{Foundation}

Supported by Program for the Philosophy and Social Sciences Research of Higher Learning Institutions of Shanxi (PSSR) under Grant No. 2013304.

\section{References}

[1] Li, W.J. and Yang, G.L. (2014) Knowledge Mapping Analysis of Intelligence Science in Recent Five Years. Information Science, 32, 104-109.

[2] Zhao, R.Y. and Wang, J. (2011) Knowledge Mapping Analysis of Library Science. Journal of Library Science in China, 37, 40-50.

[3] Yang, G.L. (2012) Knowledge Mapping Analysis of Statistics Research. Statistical Research, 29, 109-112.

[4] Lian, T.H., Yu, C.H., Zong, Q.J., et al. (2013) Mapping Knowledge Analysis of Tourism Discipline Research Based on CSSCI from 2000 to 2010. Tourism Tribune, 28, 114-119.

[5] Shao, H., Yu, Q., Bo, X., et al. (2013) Analysis of Oncology Research from 2001 to 2010: A Scientometric Perspective. Oncology Reports, 29, 1441-1452.

[6] Chen, C.M. (2006) CiteSpace II: Detecting and Visualizing Emerging Trends and Transient Patterns in Scientific Literature. Journal of the American Society for Information Science and Technology, 57, 359-377. http://dx.doi.org/10.1002/asi.20317

[7] Malkiel, B.G. and Fama, E.F. (1970) Efficient Capital Markets: A Review of Theory and Empirical Work. The Journal of Finance, 25, 383-417. http://dx.doi.org/10.1111/j.1540-6261.1970.tb00518.x

[8] Jensen, M.C. and Meckling, W.H. (1976) Theory of the Firm: Managerial Behavior, Agency Costs and Ownership Structure. Journal of Financial Economics, 3, 305-360. http://dx.doi.org/10.1016/0304-405X(76)90026-X

[9] Garfield, E. (1994) Scientography: Mapping the Tracks of Science. Current Contents: Social \& Behavioural Sciences, 7, 5-10.

[10] Chen, C.M. (2005) The Centrality of Pivotal Points in the Evolution of Scientific Networks. Proceedings of the 10th International Conference on Intelligent User Interfaces, San Diego, 9-12 January 2005, 98-105. http://dx.doi.org/10.1145/1040830.1040859

[11] Fama, E.F. and French, K.R. (1993) Common Risk Factors in the Returns on Stocks and Bonds. Journal of Financial Economics, 33, 3-56. http://dx.doi.org/10.1016/0304-405X(93)90023-5

[12] Jegadeesh, N. and Titman, S. (1993) Returns to Buying Winners and Selling Losers: Implications for Stock Market Efficiency. The Journal of Finance, 48, 65-91. http://dx.doi.org/10.1111/j.1540-6261.1993.tb04702.x

[13] Amihud, Y. and Mendelson, H. (1986) Asset Pricing and the Bid-Ask Spread. Journal of Financial Economics, 17, 223-249. http://dx.doi.org/10.1016/0304-405X(86)90065-6

[14] Black, F. and Scholes, M. (1973) The Pricing of Options and Corporate Liabilities. The Journal of Political Economy, 81, 637-654. http://dx.doi.org/10.1086/260062

[15] Modigliani, F. and Miller, M.H. (1958) The Cost of Capital, Corporation Finance and the Theory of Investment. The American Economic Review, 48, 261-297.

[16] Ibbotson, R.G. (1975) Price Performance of Common Stock New Issues. Journal of Financial Economics, 2, $235-272$. http://dx.doi.org/10.1016/0304-405X(75)90015-X

[17] Shleifer, A. and Vishny, R.W. (1997) A Survey of Corporate Governance. Journal of Finance, 52, 737-783. http://dx.doi.org/10.1111/j.1540-6261.1997.tb04820.x

[18] Diamond, D.W. (1984) Financial Intermediation and Delegated Monitoring. The Review of Economic Studies, 51, 393414. http://dx.doi.org/10.2307/2297430

[19] Daniel, K., Grinblatt, M., Titman, S., et al. (1997) Measuring Mutual Fund Performance with Characteristic-Based Benchmarks. Journal of Finance, 52, 1035-1058. http://dx.doi.org/10.1111/j.1540-6261.1997.tb02724.x

[20] Kahneman, D. and Tversky, A. (1979) Prospect Theory: An Analysis of Decision under Risk. Econometrica, 47, 263291. http://dx.doi.org/10.2307/1914185 